\title{
Persuasion in Business Negotiations: Strategic Orientations and Rhetorical Argumentation
}

\author{
Kestutis Peleckis", Valentina Peleckiene \\ Faculty of Business Management, Vilnius Gediminas Technical University, Lithuania
}

Copyright (C) 2015 by authors, all rights reserved. Authors agree that this article remains permanently open access under the terms of the Creative Commons Attribution License 4.0 International License

\begin{abstract}
When strategically planning negotiating speech it is desired to avoid coincidences and to choose the most appropriate means to achieve its objective. Implementation of the strategic orientations is associated with each aspect of the language. Negotiating, in other words, it is a public speaking in the negotiations, is a strategic process, which includes an understanding of the circumstances, the deliberate behavior and a plan how to achieve your goals. During the time of negotiating the negotiators together are creating a commonly significant thing, their thoughts, opinions, attitudes and values are tested, adapted, developed through interaction. Negotiators approaches of different cultures can vary significantly. For one negotiator some things and facts may be more important or more significant than for others, and his attitude towards them will determine how he will interpret and understand the statements which he have heard. The paper deals with the problems of rhetorical effect to other side of the negotiations. It is argued that a persuasive speech is very important competence of negotiator, as nothing can change negotiator's alive speech. Only directly negotiating, giving evidence, arguments, counter-arguments, controversy negotiators can move quickly to the overall objective of the agreement. Even with a well-developed modern means of communication, the Internet, electronic negotiation support systems, negotiators are moving to another part of the world for direct negotiations. Negotiator in alive bargaining process demonstrates himself, his appearance, mind, manners, emotions, ethics, etiquette knowledge, characteristics of voice, gestures, movements, facial expressions, reactions and their other communication options. The use of rhetorical tools in bargaining process, the success of staying in contact with the other half of the negotiations is an important factor for effective negotiations. If classical rhetoric focused attention on how to convince the other part, in modern rhetoric, focus is focused more to dialogue, to interaction between speakers, and harmonization of relations.
\end{abstract}

Keywords Strategic Orientation, Rhetorical Argumentation, Negotiators Rhetoric, Business Negotiation,
Persuading the Opponent, Logical Reasoning, Negotiator Fervor, Ethics of Reasoning

\section{Introduction}

The negotiation in business take place constantly: making the purchase and sale agreement (contract), appointment and dismissal of employees, dealing with a variety of situations. Business meetings or negotiations can take place easily or with high voltage, may be able to easily negotiate or deal with special problems or a whole fail to agree. Communicating efficiently, understanding psychology of the other human or negotiating partner, and the interests of the organization he is representing, mostly determines success of business meetings and negotiations. To do this well, one needs to assimilate basics of communication, be able to read verbal and nonverbal communication signs, expressions, to have the created system for preparation to interview and negotiation to be able to provide and receive information to substantiate their positions, to respond to comments are neutralize them, to understand, to resist the manipulations and know how appropriately to complete the negotiations.

Strategies of the negotiating speech are focused on future speech, negotiating activities and are associated with the prediction of the possible negotiation, rhetorical situations. It is important to know the motives and interests of the other side of the negotiation. Negotiator with his speech encourages other side of the negotiations to start something, to change something, to complete something, affects the values, attitudes, provisions, makes an impact on decision-making. The negotiators making influence are expecting from the other side of the negotiation the corresponding and predictable reaction. In process of arguing are involved both negotiating sides - one side uses the tools of persuasion and another side - more or less replace its beliefs or firmly comply with its views.

The negotiating parties are trying to convince each other in the correctness of their views, positions in business 
negotiations. For this purpose, using a variety of tools starting from logic diagrams and finishing with various appeals, speculation, sophistries [6], [8], [19], [20], [21], [22], [18]. Rhetoric extending from Aristotle, is "not only as the word art to persuade, but also as structured science of persuasive speech with its own structure, definition, terminology, categories, rules" [9]. Persuasive speaking is very important competence of the negotiator. Nothing can replace the persuasion of a live word by the negotiator. Only directly negotiating, submitting evidence, arguments, counter-arguments, polemicizing, negotiators can move quickly towards the joint target of the agreement [1], [5], [7], [11], [17], [16]. If in the rhetoric of Aristotle communication act was a one-way, so the modern rhetoric says that there are no passive sides in the act of communication - and the speaker and the listener are playing an active role [2]. Even with a well-developed modern means of communication, the internet, electronic negotiation support systems, negotiators move to another part of the world for live, direct negotiations. The negotiator in the process of a live negotiating exhibits himself, his look, mind, manners, emotions, ethics, etiquette knowledge, features of his own voice, gestures, movements, facial expressions, and other reactions of his communicational capabilities [12], [13], [14], [15]. As indicated R. Koženiauskienè, "in rhetorical theory the rhetorical tools are estimated at several hundreds, and they are quite different, each has its own purpose, carry out certain functions, helps to influence the addressee. Theoretically, all the rhetorical tools are neutral, their positive or negative influence is determined by the speaker's purpose and the circumstances under which the instrument is being used... Rhetorical measures primarily have to embody and help to clarify the content, to convey and clarify certain information, reinforce arguments, to lead by the way of wisdom, truth and proof, rather than oratory. Knowledge of rhetorical tools helps to reveal a logical order, the consistency of the information provided, the links of sentences causality. Another important feature of rhetoric tools is to maintain a successful contact with the audience" [9]. The use of rhetorical measures in the negotiating, the success of staying in contact with other part of the negotiations are important factors for effective negotiations. If classical rhetoric is focused on how to convince the other part, so in modern rhetoric greater focus is on the dialogue, mutual interaction, harmonization of relations between speakers [9]. In the negotiations for rhetoric is highly appropriate saying by S. Palazzi: "rhetoric - that is to say the right things at the right time in the right place at the right way to attain the chosen goal" [9]. Thus, the rhetorical competence of the negotiator could be described as the ability to speak well, to prove, to argue, to use correctly, properly rhetorical measures necessary to evaluate the bargaining situation, the context of the negotiations, the peculiarities of communication (rhetorical) situation, be able to analyze and critically evaluate own discourses and of other negotiator, to reveal the cause of effective and ineffective speaking, recognize manipulation and bluffing, to know how to convince the other side of the negotiation.

Problem. The lack of strategic orientations, objectives and appropriate measures to achieve them in negotiator's speech can become an essential barrier for effective negotiation results.

The object of investigation - the negotiator's speech, its rhetoric of strategic orientation.

The aim - to reveal the essential elements of negotiator's rhetoric strategic orientation, enabling the formation of more effective negotiator's speech, to achieve better negotiating objectives.

Research methods - the systematic, comparative, logical analysis and synthesis of scientific literature.

\section{Strategic Orientation of Negotiator's Rhetoric}

Negotiator's speech rhetoric - the set of methods and techniques of persuasion with the help of which speaker tries to influence the other side of the negotiations through his speech content and form, evaluating peculiarities of listeners, seeking to reach his goals sophistries [6], [8], [19], [20], [21], [22], [18]. Rhetorical orientation of negotiator's language provides a purposeful impact on the other side of the negotiation through language content ( evidence, arguments ), through speech composition, its structure and style of speaking, through para verbal elements of speech (voice use features - intonation, articulation, pauses, accents, timbre, tone, speech rate, speech volume, melody, etc. ) [3], [9], [10], [12], [13], [14], [15]. The adequate assessment of negotiating situation and the characteristics of the other side of the negotiations (values, attitudes, beliefs, needs, interests and so on. ) enables to select and compose strategically appropriate evidence and arguments, to plan their submission form and procedures leading to the final goal of the negotiations agreement [1], [2], [5], [7], [11], [16], [17].

Strategy of the negotiating speech covers set of actions and measures that will be used to achieve goals, focusing on negotiating a favorable solution of the situation. Strategically planning of the negotiating language is desire to avoid coincidences and choose the most appropriate means to achieve its objective. Strategy of negotiating speech - it is aggregate applicable tactics and actions in the negotiator's speech, which are related to behavior prediction of the other side of the negotiations and overcoming resistance or confrontation to attain the desired purpose of speech. Strategy has a hypothetical nature in respect of future situations and is associated with a higher or lower probability due to possible changes of situation and behavior of another negotiating side. These processes can't be made up by algorithm, can't be managed in accordance with certain rules, because each interaction of negotiators is unique.

The negotiator in negotiating language often has following objectives [22]:

- giving new information or an opinion;

- making positive or negative impression; 
- strengthening the beliefs;

- beliefs attenuation;

- beliefs change;

- the promotion of a particular act.

The negotiator seeking for the final purpose of his language can combine several sub-goals that lead to the overall score: to inform the other side of the negotiations, to provide new data, to cause relevant emotions, to affect the opponent's beliefs, and attitudes and to incite the relevant actions. Negotiator language purpose - is the final result, which he hopes to achieve with the help of his own language, using the strategies and tactics in one or another form.

Negotiator when planning to achieve certain goals, formulates appropriate tasks according to negotiating situation, his own opportunities, the negotiating positions and the potential of the other side of the negotiation. If there are well-identified conditions affecting one or the other result of the negotiation strategy, it is possible to predict that certain tactics and actions with high probability will give a good outcome of negotiations. However, further, more in-depth analysis and new specific situations of negotiators interaction can't approve the forecast. The targets for new information presentation and inclusion into the mind of other side of the negotiation are implemented through communication strategies. Objectives, in order to cause positive or negative feelings to another side of the negotiation, are carried out by using the information and persuasion strategies. The targets devoted for conviction, strengthening or weakening the radical views of its members and the promotion of a particular modification activities for other side of the negotiations are pursued through persuasion strategies [22].

In some cases, information strategies that are used by negotiator have elements of persuasion. For example, as information using the few things comparison can convince the other side of the negotiation on advantage, usefulness, ease of one thing or another and thus provide the basis for a decision. Implementation of the strategic orientation is associated with each aspect of the language [22]:

- how will be argued and how will be drawn conclusions;

- how will be prepared speech ;

- what material will be used for justification;

- what formulations will be selected;

- how will be displayed the emotions, feelings

- what will be repeated;

- how will be said in speech

\section{Situational Factors in the Rhetoric of Negotiator}

Situational factors are very important for language of negotiator. As D. Zarefsky notes "Language is good not because it was created by some formula, but because of the possibility to fit effectively in particular situations. Language which is suitable for one situation may be worthless in other cases" [22]. D. Zarefsky notes: "Each time when you are preparing for public speech, you will have to decide individually on your objectives and most appropriate methods to achieve them" [22]. These methods and practices are associated with strategy - "and just then when you are choosing, in response to the situation, your model of choice really helps to identify it. The situation has an impact on you, but you're also doing it [22]. Negotiating, or in other words public speaking in the negotiations is a strategic process, that "involves understanding of the circumstances during speech presentation, the deliberate behavior at that time and plan preparing to achieve your own objectives "[22].

During the negotiations negotiators are working on joint significant thing, their thoughts, opinions, attitudes and values are tested, adapted, developed through interaction. The attitudes of different cultures of negotiators can vary significantly. One thing or facts may be more important or significant for a specific negotiator than others, and his attitude towards them will result in fact how he will interpret and will understand statements listened. During the preparing for speech of negotiations and presenting it, the negotiator needs to know extremely well:

- the object of negotiating (product, service, relationships, and exchange project, etc..);

- his opponent - negotiator;

- organization, represented by negotiator - opponent.

As negotiating language strategies are focused on the future actions of speaking, negotiating and are associated with the prediction of possible rhetorical situations of negotiating, it is important to know the interests and motives of the other side. The negotiator with his language encourages other side of the negotiations to start something, to change something, to finish something has an impact on his values, attitudes, provisions and affects the decision-making process. The negotiator when making the impact expects from another side of the negotiation the appropriate, predictable response. In the process of persuasion are involved both negotiating sides - one side uses the tools of persuasion and other - changes his beliefs more or less, or keeps strongly his own views. The impact on the negotiating process can be determined by following factors:

1) greater negotiating powers on one side (personal characteristics, standing, excellent reputation, higher status, higher emotional intelligence, charisma, etc.);

2) bluffing, manipulation,

3) substantial evidence, arguments.

The acknowledgement of negotiating object, the opponent and his organization, the preparation for this requires that the language of the negotiator would comply more or less with the expectations of the other side of the negotiations, because the success of achievement the negotiation objectives depends on the opponent's reaction. Consequently the opponent has an impact on both: the negotiations and the rhetorical situation, forcing the speaker to choose: what thoughts to highlight, or stress, what information and how to submit it, how to prepare a speech, evidence, arguments, and 
what goal to choose. In turn a well-designed speech can correct the opponent's-negotiator's understanding about the negotiation situation when significant arguments are presented, when speech is enthusiastic. The beliefs, attitudes, dispositions, values of other side of the negotiations are the starting point of the negotiator's speech strategies development. Of course, each negotiator as every person wishes to confirm his position but it could be done and by emphasizing their relationships in beliefs, attitudes, provisions and values of their own and the other side of negotiations.

The impact on another side of negotiations can be associated with the use of both positive and negative incentives. Measures of positive effects can be: promises, demonstration of benefits to another side of negotiations, sympathy demonstrations, bribery, appeal to the debt (by reminding sometime made a discount), the appeal to altruism, appeal to authority, the moral imperatives of self-worth emphasis, the assessment of opponents-negotiators positive personal traits, aversive stimulation - when are removed previously declared sanctions and other. Measures of negative effects can be: threats, demonstration of the damage to another side of negotiations, sanctions, and so on.

The negotiator with own speech is trying to make influence on other side of negotiation. Whole speech of negotiator has an ultimate goal, and each element of the speech (action) has a corresponding sub-goal. There are no pointless actions, but a set of actions of negotiator that are based on his motivation, interests, needs. Negotiator's speech has a strong relationship with his motives, needs, interests and desires. Each negotiator wants to achieve results that would be maximum positive and minimum negative. The negotiator has an impact on the other side of negotiation, which usually can be free in choosing their actions and tactics, based on their needs and interests. The values, attitudes and provisions of one negotiating side during negotiations are more or less oppose against the values and attitudes of other side of negotiation. Effect of peer influence occurs in negotiations when both negotiating sides are coming up to each other within the limits of acceptability.

In negotiating, the negotiator during presenting his evidence and arguments, is followings how reacts his opponent to his outspoken ideas, proposals, (how he listens, what is his body language - mime, nods in agreement, disapproval, glimpse when he did not understand, etc.) seeking to understand the reactions of responses and to take this into account. When the negotiator is speaking, his opponents are interpreting in their own way his outspoken thoughts.

When negotiating, one side of negotiations examines, compares to his opinion the provisions, values and ultimately reacts accordingly to other side of negotiations. The response in negotiations by non-verbal ways, body language signs, helps negotiator to feel: whether they are coming up toward achieving the goals or moving away from them. Therefore, ability to read the body language for negotiator is very important. If the body signs of one side of negotiations are speaking about the fact that the most important idea was not understood - it should be presented and explained for them in detail at the appropriate moment.

Negotiating is a response to a specific negotiating and rhetorical situations, which include the specific circumstances. Therefore, the speeches of negotiators have to answer to the questions which situations have posed. This can be sharing of information, exchange of information or persuasion with the other side of negotiations, when in the process of making decision of situations can be formed, developed, approved, amended or strengthened approaches, attitudes and values of negotiating party, stimulating to work together or to delay negotiations, encouraging them to act, to do nothing or stop negotiations, maybe and further relationships.

Your goal is to create a strategy - an action plan to reject the restrictions and to take advantage of opportunities "[22].

D. Zarefsky notes that the speeches are spoken in order to achieve the desired objectives, so the most important measure of quality, is the "achievement of objectives which speech succeeded in. Three main objectives of the speech are:

- to give for the audience a new information or new ideas;

- to convince and influence attitudes and behaviors of the audience (to reinforce an existing one, either based on a view);

- to interest and awaken a feeling of community by highlighting relationship among speakers and listeners.

These goals may seem completely different, but they often coexist in one speech, when speaker seeks to share the new information and use it to influence other people's attitudes and behaviors (or awaken feeling of community) [22]. However, "the achievement of its objectives is not the only measure of quality in assessing speech) "[22].

Does bargaining will be successful, it largely determines how the negotiating parties shall establish their connections. After all, the two sides are wishing to see the interest in their positions, evidence, arguments that would be an adequate response to them ... D. Zarefsky notes that "we do not keep successful speech with which the listeners were misled or they were manipulated, even if the speaker have reached the desired goal "[22]. "The power of speech is overwhelming and speaking man assumes a huge responsibility. Public speakers are seeking to influence others, to change the audience views, values or behavior. "[22]. As a speaker, you must be extremely ethical [22]:

- have respect for the audience;

- to respect the chosen theme;

- be responsible for your own statements;

- be responsible for the effects of speech.

Ever saying the negotiating speech it is appropriate to use D. Zarefsky proposed principles [22]:

- take into consideration approach of another side of the negotiation, whatever it may be. One of the respect 
signs to other negotiating side is our willingness to recognize its attitude and make it as your starting point in negotiating process;

- not to use phrases that the other side of the negotiations could interpreted it as degrading them.

- The negotiator must answer for accuracy and the fairness of his statements:

- to respect the competences of another side of the negotiation. In order to defend one attitude, you must explain why it is superior to the other, but not pervert and refuse opinions, you do not like;

- respect cultural diversity. When respecting cultural diversity it is necessary to look to your attitude and resist the temptation to believe that all the others support him.

\section{Sources of Persuasive Impact on to the Opponent in Business Negotiations}

The most important function of rhetoric is persuasive impact, covering very extensive range to other person (or group of persons) - from persuasion, suggestion, inspiration, faith reinforcement, encouragement till captivating [10]. What are the sources we can use? Aristotle in his "Rhetoric" appointed much attention for rational arguments in persuasion, the appealing to the logos, that is to the mind thinking, reasoning and consideration, but also provided an important role for other factors of persuasion - ethos and pathos [9]. R. Koženiauskienė [9] and Z. Nauckūnaitė [14] present the most important features of logos, ethos and pathos (Table 1).

Table 1. Characterization of definition content on persuasive impact sources

\begin{tabular}{|c|c|}
\hline $\begin{array}{c}\text { Source of } \\
\text { persuasive } \\
\text { impact on the } \\
\text { opponent }\end{array}$ & Characterization of definition content on persuasive impact source \\
\hline 1. Logos & $\begin{array}{l}\text { Logos is designed that speaker with accurate and clear words can convince listeners, affect them by professional freedom of } \\
\text { thoughts and speech logic, wisdom and the right words seeking to their goals. Logos - it is an appeal to the mind, or a synonym of } \\
\text { justice criterion, it is faithfulness to the truth. Logos - it is the facts, events, actions, clear evidence supporting by witnesses, and } \\
\text { documents, expert conclusions, language [9] } \\
\text { Logos principle states that in order to convince the audience, addresser must consistently provide the evidence and follow the logic } \\
\text { of the rules - regular course of reasoning. It seems that logic and rationality should be seen much more than the image of the } \\
\text { addressee or the addressee's appeal to the emotions, but the formal reasoning of addressee is usually unacceptable (heavy and } \\
\text { boring), so have to rely on rhetorical reasoning types. For this reason, the ratio of quality of the evidence and of persuasion } \\
\text { categories is discussed so far [14]. }\end{array}$ \\
\hline 1. Ethos & $\begin{array}{l}\text { Ethos - is loyalty to yourself, everything what is related with the ethics and etiquette - the speaker's general values, the ability to } \\
\text { listen and understand the other person, to adapt the words of the topic, audience, circumstances, with respect to the law, as well as } \\
\text { to the ordinary citizen, to the listener, to the opponent. This is the respect that is shown by the behavior and expressed in appropriate } \\
\text { words. Ethos arguments appeal to the speaker's and the listener's moral norms (justice, fairness, a sense of responsibility) } \\
\text { commonality. Usually there are two kinds of psychological arguments: } \\
\text { 1) arguments of understanding and acceptance, in order to characterize a person, and } \\
\text { 2) the arguments of general condemnation, in order to characterize the behavior. In fact ... ethos - is an appeal to human behavior } \\
\text { (suggestion and linguistic behavior), or synonym of sincerity criterion. Each speaker is allowed to claim only what he believes } \\
\text { himself. Aristotle ... said that we listen not to the language but to the person who is speaking, and had opinion that from all three } \\
\text { categories most persuasive is ethos. Values and beliefs ... or personal moral authority, becomes the basis of rhetorical appeals [9]. } \\
\text { Ethos refers to the speaker's moral qualities. From Greek language ethos arose ethics, ethical, and modern communication science } \\
\text { ethos tends to interpret by the word image because Aristotle ethos used to describe such features of the speaker's character, which } \\
\text { he reveals to the audience. Aristotle said that we tend to trust more the speaker, who is "wise, honest, and kind-hearted." Today near } \\
\text { the features of the common sense, as good character and good will are attached the competence - addresser must be not only a great } \\
\text { man, but also well versed in the subject matter about which he is speaking or writing. Therefore, when writing argumentative text, } \\
\text { ethos, as the image of author is created by: } \\
\text { a) choice of tone and style, a discursive manner suitable for the top of our society; } \\
\text { b) displaying an excellent understanding of the subject [14]. }\end{array}$ \\
\hline 2. Pathos & $\begin{array}{l}\text { Pathos, according on today's understanding are speaker's emotions - everything that shows the strength of the speaker's position, } \\
\text { his sincere determination to defend justice and explain the truth after the movement of the audience's feelings. Aristotle's pathos ... } \\
\text { - is an appeal to the senses, and the most important - the ability to put themselves in another person's emotional state, nowadays } \\
\text { commonly called empathy, which is a synonym of relevance criterion (relevance is understood as mutual feelings of fulfillment, } \\
\text { balance between the speaker's and the listener's emotions). ... Relevance criterion requires that the speaker might know the } \\
\text { audience emotions and starved the same, what feelings he expects from the audience, that he do not go from the subject, do not lie, } \\
\text { do not to play, that he would be sincere[9]. } \\
\text { Pathos refers to the speaker's ability to connect with audience's feelings, desires, wishes, fears and desires. Assessing in the } \\
\text { addressee's perspective, it is necessary that the addressee would hear and understand you (if you are unable to connect with the } \\
\text { audience, do not neither speak nor write). Evaluation the contact from the view point of audience, is dangerous because it can easily } \\
\text { become a victim of manipulation: after all, the decisions often are not based on rational reasoning - the strongest impact on human } \\
\text { decisions, according to Aristotle, has anger, pity, fear, and contrary to their feelings [14]. }\end{array}$ \\
\hline
\end{tabular}




\section{Logical Proof and Argumentation in Business Negotiations}

Knowing the opponent's persuading by his logical evidence and arguments, we can say that bargaining in business negotiations should be accurate, precise, specific, logical. Any logical errors of the negotiators are violations of one or the other requirements of the Logic law, that is the Law of Identity (Latin Identitas), the Law of Contradiction (Latin Contradictionis), the Third is not given Law (Latin Tertium non Datura), the Law of Sufficient Ground (Latin Rationis Sufficient) or otherwise.

The Law of Identity requires that in business conversations or in negotiations the thought, the statement, the notion expressed by chatter or the opponent during the entire conversation or negotiating period would mean the same. Formally, this law can be expressed by the formula: A $=\mathrm{A}$. If you said in negotiations that you are selling complete set of services $(a+b+c)$ as a unit and can't be other options, so any other your manipulation combinations of services $(\mathrm{a}+$ $\mathrm{b}, \mathrm{a}+\mathrm{c}, \mathrm{b}+\mathrm{c})$ - already conflict with Identity law.

In accordance with Law of Identity it is important that both sides of business talks or negotiations would have the same understanding of the thesis. Also submitted statement must be unique, not ambiguous or not defined. It seems that it is very simple requirement but not always it succeeds to express an idea on adequate language structure.

Frequently are occurring errors in business talks and negotiations, which arise from ambiguity of words and phrases. These errors are divided into 3 groups:

- Equivocal (Latin aequivocus - ambiguous) errors (due to multiple meanings of words). They are occurring when in conversation or business negotiations ambiguous words are used for one or another value, assuming that it is presented clearly;

- Logomachy (logo + gr. machia - fight) errors (due to lack of commonality of topics for conversation, jumping from topic to topic);

- Amphibology (gr. amphibolia - ambivalence, ambiguity) errors (ambiguity resulting intonation, sentence structure, punctuation errors).

The Law of Contradiction (formed by Aristotle) argues that two conflicting statements - a statement and its denial cannot be true at the same time (is not true that A and non-A at the same time are correct). If the thesis is considered to be true, then the antithesis acquires significance of lies. An example: If the thesis is: "This is an honest businessman," it is the antithesis - "This businessman is dishonest "- a lie.

The Law of Contradiction has a very important significance in business talks and negotiations. Consciously using it is possible to detect and eliminate the contradictions of claims, critically evaluate claims and inaccuracy of behavior and incoherence. Law of Contradiction is commonly used when you need to prove something: if it is established that one of the most controversial statements is correct so the other statement is incorrect. Determination of controversy of the chatter, the opponent claims is one of the strongest arguments in defense of their position. If in business conversations, negotiations are not violations of the Law of Contradiction - that means that the other speakers, negotiators statements and thoughts are assured in any way logical link between statements.

The Third is not given Law argue that from the two conflicting statements one must be correct. Its essence is as follows: available or as stated, or as describes his denial there is no a third possibility. Formally, it is expressed by the formula: true A or not A. If the statement: "Our enterprise is competitive in Lithuania" is correct, so the statement: "Our company is not competitive in Lithuania" is wrong.

The Third is not given Law is important in business talks, negotiations, because it requires a certain consistency in facts and demand to avoid contradictions in statements. From this Law arises a requirement for business talks, negotiations: it is not allowed not to recognize one of the conflicting claims and to search for the third among them. If one of the following statements is recognized as correct, so contrary to his assertion it is necessary to recognize a wrong one and do not try to look for a third option that does not exist, because it cannot be.

Law of Sufficient Ground says: "The claim is correct, if it is sufficiently reasoned. To prove correctness of claim "Sufficient reason" might be another idea or any claim. Why it is said "sufficient reason" and not "ground"? Because for reasoning of the claim can be found innumerable amount of grounds. However, only some of them can be considered to be sufficient, of course, if the same statement is correct. No one ground will be insufficient if the claim itself is false. Let us take sophists who are trying to prove obviously false claims. Trying to justify their own statement they provide the basis which is not sufficient. Basis is sufficient when it proves the correctness of the statement.

Implementation of Law of Sufficient Ground in business conversations, negotiations requires that each expressed attitude, the statement must be sufficiently justified. Paying proper attention to validity of the opinion, we can distinguish the correct statement from the incorrect, false. In argumentation process in expressing and disclosure of logical relations induction and deduction have highly importance. Induction - is a method of reasoning, when summarizing separate partial statements some conclusion are done. Deductive reasoning - contrary than induction - is method of reasoning when from general statements are made narrower conclusion useful for partial, particular cases. So, in induction - conclusions are derived going from the partial to the total, and in deductive reasoning on the contrary. Induction - can be complete and imperfect. Complete induction provides the conclusion which is done after examination of all possible individual situations. However, this is usually impossible. Therefore, imperfect induction is used. For example, public surveys - there is interviewed only a certain part of society, and the conclusions are made about the whole society. Imperfect induction are of 3 types:

1. Simple monitoring (if all observed facts support the conclusion - so it is summarized that it is typical for 
everyone in that kind of facts);

2. Fact selection (when are discarded random facts that can't be attributed to the findings);

3. Scientific induction (will not be touched because it is not the object of this work).

During the negotiations, business talks there are always applicable simple observation and selection of facts induction methods. However, the usage of the method on facts selection often in business talks are performed by some manipulations - useless facts, figures, data suppressed. Sometimes can be made and summarized irrelevant facts aiming the agreement in the negotiations. Therefore, the facts, the statements must be checked in one of five ways:

1. Determine if the correct facts or claim form the basis for aggregation, findings. Sometimes inaccurate facts, figures, statements can make highly doubtful and of aggregation and the same recipient or opponent.

2. To examine whether the claim has a connection with the conclusion. Let's say that a brand of wood lacquer is less expensive than lacquers B, C, D. It seems that it can be concluded that the best interest to buy a brand of varnish. However, such a conclusion would be wrong, because is not detailed lacquers $\mathrm{B}, \mathrm{C}, \mathrm{D}$ performance ratio. A lacquer is defined only in terms of price. Better lacquers B, C, D quality makes them more useful for lacquer $\mathrm{A}$. This is a typical inductive reasoning error.

3. Determine whether enough is given the information, examples, facts. To solve this problem, it is necessary to take into account not only the number of facts but also into the sample which aims to ensure representativeness. For example, if you investigate cases of incompetence only of 2 businessmen it follows that all the Lithuanian businessmen are incompetent will be wrong. In Lithuania there are hundreds of thousands entrepreneurs. Therefore, several cases of malpractice can't provide a basis for such a finding.

4. Determine if the selected examples, cases, the facts are typical. This method is closely related to the previous method, because the number of samples depends on how much they are representative.

5. Determine whether there are negative examples, to which should be paid attention. The negative example is an example that does not feed into the conclusions. This is an exception to the rule.

If the speaker's opponent is aware of such negative examples he alone can deny the arguments. In business conversations and negotiations is essential such option of induction as reasoning on causation. Causation - that is interdependence between two or more events, when one phenomenon (reason) is the base to occur to another (the result). For example: prices of oil went up - it means that will become more expensive gasoline, diesel fuel.

In any case of dispute, the causal logical connection should be checked in accordance with the following rules:

1. Can occur perceived phenomenon, when not available the presumed reason? If the answer is - yes, it can't be said that before the consequence going phenomenon is the only reason for the consequences. In this case, it can be said that either there is no connection between the two phenomena, or is another possible cause.

2. Does happen that there are no consequences when the reason is obvious? If the answer is - yes, it can't be said that this seems to be the only possible cause. Or there is no connection between these events, either it is another possible consequence.

3. Is there a relationship between implicit and perceived cause of the phenomenon is not accidental, but conceived as causal because of the events following each other in time and space. An example: it is argued that limiting alcohol and beer advertising in the media significantly decreased alcohol consumption. But there at the same time was increased the excise on alcoholic beverages. As a result their price increased. So decline in the purchase of alcohol outlets may be affected by the increase of illegal homemade vodka production volumes, consumption of contraband alcohol, growth of surrogates volume.

4. Are there other possible causes? Sometimes we are interested in the cause may seem more important than the real main cause.

5. Are there other potential consequences? Cause-effect reasoning is oriented to the future, because of changing reasons, conclusions are drawn about the possible consequences in the future. However, in most cases no one is taking to check the validity of such predictions and evaluation of other effects.

The arguments will be logical and form the basis logically to prove and justify the position if they comply with the following requirements:

1. The arguments can be considered only those statements that are accurate or nobody doubts them;

2. The arguments will be proven independently regardless of the thesis (they must have self-validity);

3. The arguments must be consistent;

4. The arguments must be sufficient.

\section{Ethics of Argumentation and Persuasion in Business Negotiations}

In terms of ethical reasoning should be noted that the bargaining requires cooperation. But it is possible only in mutual trust and responsibility conditions. Therefore rhetorical ethos is manifested in two aspects:

1) the negotiator speech quality that gives the other side of the negotiation the basis for confidence in the speaker;

2 ) the other side of the negotiation features encouraging the speaker to be ethical.

As observed by D.Zarefsky "self-perception has an impact on how you will be perceived by the listener. Does they accept you as a knowledgeable and well-informed or as arrogant and proud. In the first case, you can expect that the 
audience will support your efforts to share information and ideas, in the second case people can outrage that you have explained to them what to do" [22]. There also D. Zarefsky emphasizes that critical self-assessment will tell you how to change to obtain better their own ethos. Sometimes for the purpose you have little things to change. For example, different wording, such as "all remember" instead of "I want to remind you, can help to create a sense of community and will not be highlighted your advantage, and dependence of the listeners. Focusing on this aspect of the ethos especially is important when the audience is culturally diverse" [22].

Evaluation of your ethos as indicated D. Zarefsky, is advised to consider all your significant and future listeners similarities and differences that have an impact on listeners approach to you. Change what would improve the perception of the listeners to you but remain yourself. Analyze yourself, as you control your behavior affecting the listener's view of your ethos" [22]. As observed by D. Zarefsky, to adapt to the listeners is not difficult, because the speaker basically control their behavior. According to which the audience evaluate its ethos. Finally, you can choose whether to maintain eye contact, smile, frown, or make a pause, and so on. You make a decision by what underlying material to use, how to lay out it, how to gesticulate.

All that you control, so you can affect the audience's opinion of yourself. Of course, you would like those listeners your ethos welcomed, and not just because of the fact that you like when others well think about you. Aristotle said that the real way of the speaking may be the most important tool to convince the listener. The fact of how listeners perceive your ethos will be affected by what they will think about your speech [22].

Argumentation ethics in negotiations is concerned with the rules that are equally recognized both by the speaker, as well listener. Rhetorical ethic is concerned on compliance with morality, ethics, etiquette, law, as well as the technical norms of language. Despite the importance of norms, negotiation ethics, including the ethics of negotiating language is not limited to them. Rhetorical negotiation involves ethics and cooperation conditions of communicating parties.

When negotiating, discussing, evaluating facts, preparing and making joint decisions occurs a new negotiating experience that summarizes and creates a new reality, which is determining further actions of negotiating party and conditions in which the negotiating will take place in the future. This process inevitably more or less may be vulnerable for particular rules and regulations. In the light of these consequences of violation, norms and rules can be extended and supplementary narrowed or - if the negotiator language, his proof, the arguments are ethically unacceptable. Negotiating language governing norms are related to the use of languages in the negotiations, freedom of speech (and abuse), the freedom of conscience, copyright and intellectual property, privacy, confidentiality, goods and services, advertising and other things. Observance of ethical norms is associated with the adequacy of the bargaining language, speaking order and consistency, the right to the appropriate language. Here is an important language style to ensure its accuracy, precision, and clarity. It must be not forgotten responsibility for misrepresentation, bluffing, manipulation, psychological, emotional pressure to the other side of the negotiations, compliance with the rules of etiquette and politeness.

For ethics of negotiating is important to ensure the following conditions:

1. A systematic focus on other negotiating part outlines thoughts, replics, speeches, statements. Rhetorics in negotiations begins on the desire and ability to grasp the opponent as one who listens, understands and remembers what is said, is in a better position. Ethical negotiator seeks that his opponent could fully speak. Possession of detailed information enables the selection of appropriate reasoning tactics and more productively to participate in negotiating process.

2. It is required continuous analysis of the information. The negotiator tries to separate the content of the opponents speech from his personality, to analyze the content of the opponents statements through the prism of his goals and interests, to analyze the content of the opponents statements and compare this to their own purposes and interests, distinguish in the opponents speeches acceptable part from unacceptable.

3. The use of positive information. Communication development is based on the ideas and facts that are mutually acceptable. In order to develop an effective negotiating dialogue it is needed to stop disparities and focus on matters of common interest. Thus, the evaluation of positive, leading to the common interest aspects of the opponents speeches is very important for the efficiency of negotiating.

4. Ethical negotiator submits the following statements, which are relevant to the opponent, assesses content of the opponent's statements and takes it into account.

5. The negotiator seeks his goals and interests, but recognizes the right of the opponent to have his own goals and interests, tolerates his position.

\section{Fervor of Language Negotiator in Argumentation and Proof System}

Negotiator's language fervor not always is an expression of his emotional state - he just uses such speech technology, which creates a certain emotional image. In reasoning fervor is highly essential because language individuality of the negotiator occurs precisely through the speaker's pathos, which encourages listeners to empathize with content of the speech and the proposals. In addition rhetorical argument always in negotiations has deal with matters on which there is no consensus.

During negotiations nobody discuss suggestions and problems, which are not interesting for none side of the negotiations. Voluntary contraction of other side of the 
negotiations aimed to specific targets can be activated by emotional impact. Rhetorical fervor of the negotiator refers to the speaker's position in respect of subject matter and the solutions proposed. In theory of rhetoric there are distinguished three main types of rhetorical pathos: sentimental, romantic and realistic. Each of these types of rhetorical pathos convey the appropriate emotions. Sentimental fervor in negotiating process can occur in the contras to negotiating situation, presenting it as caused by forced power of the external reality, with the ideal image of negotiator, who is suffering from spiritual conflict.

In the case of the Romantic pathos the bargaining situation is presented which can be replaced by the forces of two negotiating sides. Romantic fervor in negotiations is the most common, because it is related to the enhancement of reasoning with getting the other side of the negotiations towards common goals by offering new ideas. In addition the use of romantic pathos enables to demonstrate emotions strong and constructive. Realistic fervor is based on a real assessment of the facts and the need to change the positions of negotiating parties in accordance with the requirements of real bargaining situations.

\section{Conclusions}

1. Strategy of the negotiating speech covers set of actions and measures that will be used to achieve goals, focusing on negotiating a favorable solution of the situation. Strategically planning of the negotiating language is desire to avoid coincidences and choose the most appropriate means to achieve its objective. Strategy of negotiating speech - it is aggregate applicable tactics and actions in the negotiator's speech, which are related to behavior prediction of the other side of the negotiations and overcoming resistance or confrontation to attain the desired purpose of speech. Strategy has a hypothetical nature in respect of future situations and is associated with a higher or lower probability due to possible changes of situation and behavior of another negotiating side.

2. The acknowledgment of negotiating object, the opponent and his organization, the preparation for this requires that the language of the negotiator would comply more or less with the expectations of the other side of the negotiations, because the success of achievement the negotiation objectives depends on the opponent's reaction. Consequently the opponent has an impact on both: the negotiations and the rhetorical situation, forcing the speaker to choose: what thoughts to highlight, or stress, what information and how to submit it, how to prepare a speech, evidence, arguments, and what goal to choose. In turn a well-designed speech can correct the opponent's-negotiator's understanding about the negotiation situation when significant arguments are presented, when speech is enthusiastic. The beliefs, attitudes, dispositions, values of other side of the negotiations are the starting point of the negotiator's speech strategies development.
3. Each negotiator has own unique arsenal of measures, speech effects directed to the other side. Thus, we can talk about individual strategic negotiating style. Negotiations have their negotiating situations. There is important to distinguish for elaboration of strategic plans of the negotiating speech the narrower part - rhetorical situation. Rhetorical situation is characterized by the following factors: the audience, the event, the speaker and speech itself. A negotiating situation creates more factors: negotiator (negotiating team) from one side of the negotiations, organization represented, product or service, negotiated events, determining the need for negotiation, the negotiator (negotiating team) from the other side of the negotiations, organization represented and, finally, the rhetorical skills of the negotiators. Negotiating speech in response to a specific situation, to some extent will affect or will change and rhetoric, as well as negotiating situations.

4. The need to use only reasonable, fair arguments determines that using at least one unreasonable, unconvincing argument there is a danger that the other person, opponent in general will doubt on justice of reasoning. If the opponent, the interviewer asks, "What else can you prove it?" - that means that the arguments and their presentation form is not sufficient to convince the opponent. But not always possible to behave in contrary: more of arguments, the better it is. Endlessly increasing the number of arguments begins to provide arguments of minor importance, and perhaps even contrary to one another. Thus, the adequacy of arguments must be understood not in terms of quantity but by their meaning and convincing.

5. Rhetorical argumentation in business negotiations - it is an attempt of certain statements or evidence to convince someone to change the opponent's position or belief and acceptance position of other's side of negotiations. It is in the appropriate form presented claims which are directed to the interviewer's mind and emotions that they could evaluate, adopt or reject them. This is achieved without violence - only by persuasion. The rhetorical reasoning is characterized by the following aspects:

- examining the linkages between the thesis and its underlying claims of justice, and not the grounds on which the thesis is formulated and presented;

- it is targeted activity: attempts of logical, ethos and pathos factors to strengthen or weaken the beliefs of the interviewer, the opponent;

- it is a social activity, as it is directed to another person (or other people);

- it focuses on the dialogue and activates the other side of the negotiating react to the statements;

- it is considered the other side of the negotiations is rational, able intelligently to evaluate arguments, to accept them or deny and reject.

6. Ethics of argumentation and persuasion in the negotiations is related with the rules which are equally recognized by both the speaker and the audience. Rhetorical ethics is concerned with morality, ethics, etiquette, law, as 
well as compliance with the technical rules of the language. In Negotiating process necessarily more or less may be infringed certain rules and regulations. In view of the outcome of cases, norms and rules can be further expanded and narrowed, or - if the language of the negotiator, his proof, arguments are ethically unacceptable.

\section{REFERENCES}

[1] Andersen, P. H. 2001. Relationship development and marketing communication: an integrative model, Journal of Business \& Industrial Marketing, 16(3): 167-182.

[2] Arvanitis, A.; Karampatzos, A. 2011. Negotiation and Aristotle's Rhetoric: Truth over interests, Philosophical Psychology, 24: 845-860.

[3] Bielinienè, J. 2000. Iškalbos menas [Oratory art]. Vilnius: Dailès Akademijos leidykla.

[4] Bubelis, R., Jakimenko, V. 2004. Logika I. Dvireikšmé teiginiu logika, argumentacijos teorija. Vilnius: LTU leidykla.

[5] Eckhouse, B. 1999. Competitive Communication: A Rhetoric for Modern Business. - New York: Oxford University Press.

[6] Estrada F. 2010. Uses of the argumentation in the negotiation, MPRA Paper 22761, University Library of Munich, Germany. - Online at http://mpra.ub.uni-muenchen.de/22761

[7] Hallahan K. 1999. Seven Models of Framing: Implications for Public Relations, Journal of Public Relations Research, 11(3): 205-242.

[8] King, C. L. 2010. Beyond persuasion: the Rhetoric of Negotiation in Business Communication, Journal of busuness communication, 47(1): 69-78.

[9] Koženiauskienè R. 2009. Juridinès retorikos pagrindai. Monografija. [Basics of Legal Rhetoric. Monografy] - Vilnius: Registrų centras.

[10] Koženiauskienė R. 2013. Retorine ir stilistinè publicistiniu tekstu analize. Monografija.[Rhetorical and stylistic analysis of publicistics texts. Monografy]. - Vilnius: Vilniaus universiteto leidykla.

[11] Maaravi, Y.; Ganzach, Y.; Pazy, A. 2011. Negotiation as a Form of Persuasion: Arguments in first Offers, Journal of Personality and Social Psychology, 101(2): 245-255.

[12] Nauckūnaite, Z. 1998. Iškalbos mokymas [Oratory training]. Kaunas: Šviesa.

[13] Nauckūnaitè, Z. 2002. Klasikinè retorika kaip komunikacinès kompetencijos ugdymo paradigma [Classical rhetoric as communicative competence development paradigm], Žmogus ir žodis 1(4): 59-65.

[14] Nauckūnaitè Z. 2007a. Argumentacija: irodymo ir įtikinimo santykis [Argumentation: proof and persuasion relation], Žmogus ir žodis 9(1): 94-100.

[15] Nauckūnaitè Z. 2007b. Argumentavimas: samprata ir didaktinès perspektyvos (1) [Argumentation: Concept and didactic perspectives(1)]. Pedagogika: mokslo darbai. Vilnius: VPU leidykla, 86: 135-141.

[16] Ulbert, C.; Risse, T.; Muller, H. 2004. Arguing and Bargaining in Multilateral Negotiations, Swiss Chair, Firenze: European University Institute.

[17] Tindale, Ch. W. 2004. Rhetorical argumentation: principles of theory and practice. Thousand Oaks: Sage.

[18] Wetlaufer, G. B. 2005. The Rhetorics of Negotiations (July 23 , 2005). Available at SSRN: http://ssrn.com Zarefsky, D. 2011. Oratorystés menas. Sékmés strategijos.[ Public Speacing. Strategies for Succes]. Vilnius: Alma litera.

[19] Zarefsky, D. 2006. Strategic maneuvering through persuasive definitions: Implications for dialectic and rhetoric. Argumentation, 20: 399-416.

[20] Zarefsky, D. 2008a. Public Speacing: Strategies for Succes. Boston: Allyn \&Bacon.

[21] Zarefsky, D. 2008b. Knowledge Claims in Rhetorical Criticism. Journal of communication, 58: 629-640.

[22] Zarefsky, D. 2011. Oratorystés menas. Sékmès strategijos.[ Public Speacing. Strategies for Succes]. Vilnius: Alma litera. 